\title{
Faktor Risiko Tuberkulosis Paru Pada Masyarakat Di Wilayah Kerja Puskesmas Bambu Apus Kota Tangerang Selatan
}

\section{The Risk Factors of Tuberculosis In Community At The Work Area of Bambu Apus Health Center}

\author{
Rony D Alnur dan Rismawati Pangestika \\ Program studi Kesehatan Masyarakat, Fakultas Ilmu-ilmu Kesehatan, Universitas Muhammadiyah Prof. \\ Dr. HAMKA \\ Korespondensi Penulis: Rony D Alnur, Program studi Kesehatan Masyarakat, Fakultas Ilmu-ilmu \\ Kesehatan, Universitas Muhammadiyah Prof. Dr. HAMKA, \\ E-mail: ronyalnur@uhamka.ac.id
}

\begin{abstract}
ABSTRAK
Tuberkulosis Paru yang disebabkan oleh Mycrobacterium tuberculosis, merupakan penyakit menular yang masih menjadi permasalahan global. Saat ini, Indonesia masuk dalam negara dengan beban tinggi Tuberkulosis Paru dan menduduki peringkat ke-2 sebagai negara dengan jumlah penderita Tuberkulosis Paru terbanyak setelah India. Salah satu kelompok berisiko menderita Tuberkulosis Paru adalah kelompok masyarakat menengah ke bawah. Oleh karena itu, penelitian ini bertujuan untuk mengetahui faktor risiko yang berhubungan dengan kejadian Tuberkulosis Paru pada kelompok tersebut. Penelitian ini menggunakan pendekatan kuantitatif dengan desain studi case control. Sampel penelitian sebanyak 60 orang yang terdiri dari 30 orang penderita Tuberkulosis Paru dan 30 orang bukan penderita Tuberkulosis Paru sebagai kontrol. Data dianalisis secara univariat dan bivariat dengan uji Chi-Square pada tingkat kepercayaan 95\%. Hasil penelitian ini menunjukkan bahwa faktor risiko Tuberkulosis Paru di wilayah kerja Puskesmas Bambu Apus adalah riwayat kontak serumah dengan penderita Tuberkulosis Paru (OR: 3,5; 95\% CI: 1,11211,017; $p=0,02$ ) dan Kebiasaan merokok keluarga (OR: 4,3; 95\% CI: 1,203-15,605; $p=0,02$ ). Sedangkan, tingkat pendidikan dan kepadatan hunian bukan merupakan variabel yang berhubungan dengan kejadian Tuberkulosis Paru di wilayah kerja Puskesmas Bambu Apus.
\end{abstract}

Kata Kunci: Tuberkulosis Paru, Riwayat Kontak Serumah, Kebiasaan Merokok Keluarga

\section{ABSTRACT}

Tuberculosis caused by Mycrobacterium tuberculosis, is an infectious disease that is still a global problem. Currently, Indonesia is included in the country with a high burden of Tuberculosis and ranks second as the country with the highest number of Tuberculosis patients after India. One group at risk of suffering from Tuberculosis was the middle to lower class of society. Therefore, this studied aims to determine the risk factors associated with incidence of Tuberculosis in the group. This studied used a quantitative with a case control study design. The sample was 60 people that was 30 people with Tuberculosis and 30 nonTuberculosis patients as controls. Data was analyzed by univariate and bivariate by Chi-Square test at 95\% confidence level. The results of this studied indicate that the risk factors for Tuberculosis in the work area of Bambu Apus Health Center are household contact with Tuberculosis patients (OR: 3.5; 95\% CI: 1.11211.017; $p=0.02$ ) and smoking habits of family (OR: 4.3; 95\% CI: 1,203-15,605; $p=0.02)$. While, the level of education and occupancy density did not a variable associated with the incidence of Tuberculosis in the work area of Bambu Apus Health Center.

Key Words: Tuberculosis, Household Contact, Smoking Habits of Family 


\section{PENDAHULUAN}

Tuberkulosis Paru merupakan penyakit menular yang masih menjadi permasalahan di dunia. Penyakit ini disebabkan oleh bakteri Mycobacterium tuberculosis dengan gejala utama yaitu batuk berdahak selama 2 minggu atau lebih. Batuk dapat diikuti dengan gejala tambahan yaitu dahak bercampur darah, batuk darah, sesak napas, badan lemas, nafsu makan menurun, berat badan menurun, malaise, berkeringat malam hari tanpa kegiatan fisik dan demam meriang lebih dari satu bulan (Kemenkes RI, 2018).

Menurut WHO dalam Global Tuberculosis Report 2017, Tuberkulosis Paru merupakan salah satu penyakit dari 10 penyebab kematian di dunia. Tuberkulosis Paru juga merupakan penyebab utama kematian yang berkaitan dengan anti microbial resestence dan pembunuh utama penderita HIV. Pada tahun 2016, diperkirakan terdapat 10,4 juta kasus baru (insidensi) Tuberkulosis di seluruh dunia, diantaranya 6,2 juta laki - laki, 3,2 juta wanita dan 1 juta adalah anak - anak dan diantara penderita Tuberkulosis Paru tersebut, $10 \%$ diantaranya merupakan penderita HIV positif. 7 negara yang menyumbang $64 \%$ kasus baru Tuberkulosis Paru di dunia adalah India, Indonesia, Tiongkok, Filipina, Pakistan, Nigeria dan Afrika Selatan. Pada tahun yang sama 1,7 orang meninggal karena Tuberkulosis Paru termasuk di dalamnya 0,4 juta merupakan penderita HIV. Namun secara global tingkat kematian penderita Tuberkulosis Paru mengalami penurunan sebanyak 37\% dari tahun 2000 - 2016 (WHO, 2017).

Data dari Profil Kesehatan Republik Indonesia tahun 2016 menyatakan bahwa terdapat 156.723 kasus baru Tuberkulosis Paru BTA positif yang terdiri dari 95.382 (61\%) laki - laki dan 61.341 (39\%) wanita. $1.507(0,96 \%)$ penderita Tuberkulosis Paru BTA positif merupakan anak usia 0 - 14 tahun, 117.474 (74,96\%) penderita Tuberkulosis Paru BTA positif merupakan usia produktif (15 - 54 tahun) dan 37.742 (24,08\%) penderita Tuberkulosis Paru BTA positif merupakan lansia. Sedangkan hasil cakupan penemuan semua kasus penyakit Tuberkulosis Paru sebanyak 298.128 (174.675 laki - laki, 123,453 wanita) dengan CDR (Case Detection Rate) sebesar 60,59\%.

Hasil survei awal yang dilakukan oleh peneliti bersama dengan kader Tuberkulosis Paru di wilayah kerja Puskesmas Bambu Apus didapatkan informasi bahwa mayoritas masyarakat yang menderita Tuberkulosis Paru di wilayah kerja Puskesmas Bambu Apus adalah mayarakat pada kelompok menengah ke bawah. Berdasarkan survei tersebut, penelititertarikuntuk melakukan penelitian dengan memfokuskan sasaran penelitian pada masyarakat kelompok tersebut.

Adapun indikator pendapatan kepala keluarga berdasarkan UMK (Upah Minimum Kabupaten/Kota) digunakan sebagai acuan dalam penentuan kelompok sasaran. Adapun topik penenlitian ini adalah hubungan faktor risiko (Tingkat pendidikan, riwayat kontak serumah, kebiasaan merokok keluarga dan kepadatan hunian) dengan kejadian Tuberkulosis Paru di wilayah kerja Puskesmas Bambu Apus Kota Tangerang Selatan.

\section{SUBYEK DAN METODE}

Populasi target untuk kasus dari penelitian ini adalah semua penderita Tuberkulosis Paru dan berdomisili di Kota Tangerang Selatan, sedangkan populasi kontrol dalam penelitian ini adalah semua orang yang tidak menderita Tuberkulosis Paru dan berdomisili di Kota Tangerang Selatan. Cara pengambilan sampel dengan cara simple random sampling. Sampel diambil dengan ketentuan dasar memenuhi krit

eria inklusi yang telah ditetapkan. Sampel kasus pada penelitian ini adalah masyarakat yang menderita Tuberkulosis Paru dan tercatat di puskesmas Bambu Apus sedangkan sampel kasus dalam penelitian ini adalah masyarakat yang tidak menderita Tuberkulosis Paru dan berdomisili di sekitar rumah sampel kelompok kasus.

Kriteria inklusi dan eksklusi yang digunakan dalam penelitian ini dengan tujuan untuk memfokuskan sampel penelitian yang akan diteliti. Adapun kriteria insklusi pada kelompok kasus adalah masyarakat ( $<$ UMK Kota Tangerang Selatan: Rp. 3.555.834,-), menderita Tuberkulosis Paru yang tercatat di Puskesmas Bambu Apus, berdomisili di wilayah kerja Puskesmas Bambu Apus dan bersedia berpatisipasi dalam penelitian sedangkan kriteria eksklusi pada kelompok kasus adalah responden tidak berada di tempat saat pengumpulan data. Adapun kriteria insklusi pada 
kelompok kontrol adalah masyarakat $(<\mathrm{UMK}$ Kota Tangerang Selatan: Rp. 3.555.834,-), tidak tercatat di Puskesmas Bambu Apus sebagai penderita Tuberkulosis Paru, berdomisili di sekitar rumah penderita Tuberkulosis Paru dan bersedia berpatisipasi dalam penelitian, sedangkan kriteria eksklusi pada kelompok kontrol adalah responden tidak berada di tempat saat pengumpulan data

Penelitian ini merupakan penelitian observasional analitik dengan desain studi kasus kontrol yaitu penelitian analitik yang membandingkan antara kelompok orang yang menderita penyakit (kasus) dengan kelompok lainnya yang tidak menderita penyakit (kontrol). Pada penelitian ini kasus atau subjek dengan atribut positif diidentifikasi terlebih dahulu, kemudian sebagai kontrolnya dicarikan subjek negatif (Lameshow dkk., 1997). Penelitian ini dilaksanakan pada bulan agustus 2018 sampai dengan bulan januari 2019. Penelitian dalam rangka pengumpulan data dilakukan di wilayah kerja Puskesmas Bambu Apus Kota Tangerang Selatan.

Variabel bebas yang diteliti pada penelitian ini adalah tingkat pendidikan, riwayat kontak serumah, kebiasaan merokok keluarga, dan kepadatan hunian. Sedangkan variabel terikat pada penelitian adalah kejadian Tuberkulosis Paru. Adapun instrumen penelitian yang digunakan dalam penelitian ini berupa kuesioner yang di dalamnya terdapat beberapa pertanyaan mengenai faktor risiko kejadian Tuberkulosis Paru. Pengolahan data yang telah dikumpulkan dilakukan dengan menggunakan program komputer. Penyajian data disajikan dalam bentuk tabel distribusi frekuensi yang disertai penjelasan - penjelasan dan selanjutnya disajikan dalam bentuk tabel analisis hubungan antara variabel yaitu tabel $2 \times 2$

\section{HASIL}

Karakteristik responden yang digambarkan dalam penelitian ini meliputi kelompok umur, jenis kelamin dan tingkat pendidikan responden. Gambaran karakteristik responden menurut kelompok umur, jenis kelamin dan tingkat pendidikan responden disajikan pada tabel 1 .

Pada tabel 1, dapat dilihat bahwa berdasarkan kelompok umur, dari total 60 orang responden yang diteliti, kelompok responden tertinggi terdapat pada kelompok umur 35 - 54 tahun yakni sebanyak 33 orang responden (55\%), dimana 18 orang responden pada kelompok kasus dan 15 orang responden pada kelompok kontrol). Sedangkan kelompok responden terendah terdapat pada kelompok umur $>74$ tahun yakni 1 orang responden $(1,7 \%)$, dimana responden tersebut terdapat pada kelompok kasus.

Tabel 1. Distribusi Karakteristik Responden

\begin{tabular}{|c|c|c|c|c|c|c|}
\hline \multirow[t]{3}{*}{ Karakteristik Responden } & \multicolumn{4}{|c|}{ Kejadian TB Paru } & \multicolumn{2}{|c|}{ Total } \\
\hline & \multicolumn{2}{|c|}{ Kasus } & \multicolumn{2}{|c|}{ Kontrol } & \multirow[b]{2}{*}{$\mathbf{n}$} & \multirow[b]{2}{*}{$\%$} \\
\hline & $\mathbf{n}$ & $\%$ & $\mathbf{n}$ & $\%$ & & \\
\hline \multicolumn{7}{|l|}{ Kelompok Umur } \\
\hline $15-34$ & 9 & 30,0 & 5 & 16,7 & 14 & 23,3 \\
\hline $35-54$ & 18 & 60,0 & 15 & 50,0 & 33 & 55,0 \\
\hline $55-74$ & 2 & 6,7 & 10 & 33,3 & 12 & 20,0 \\
\hline$>74$ & 1 & 3,3 & 0 & 0 & 1 & 1,7 \\
\hline \multicolumn{7}{|l|}{ Jenis Kelamin } \\
\hline Laki-laki & 22 & 73,3 & 7 & 23,3 & 29 & 48,3 \\
\hline Perempuan & 8 & 26,7 & 23 & 76,7 & 31 & 51,7 \\
\hline \multicolumn{7}{|l|}{ Tingkat Pendidikan } \\
\hline Tidak Sekolah & 2 & 6,7 & 0 & 0 & 2 & 3,3 \\
\hline SD & 5 & 16,7 & 8 & 26,7 & 13 & 21,7 \\
\hline SMP & 9 & 30,0 & 4 & 13,3 & 12 & 21,7 \\
\hline SMA & 12 & 40,0 & 15 & 50,0 & 27 & 45,0 \\
\hline Perguruan Tinggi & 2 & 6,7 & 3 & 10 & 5 & 8,3 \\
\hline
\end{tabular}


Pada tabel 1, juga dapat dilihat bahwa berdasarkan jenis kelamin dapat diketahui bahwa dari total 60 orang responden yang diteliti dapat diketahui bahwa kelompok responden tertinggi terdapat pada kelompok dengan jenis kelamin perempuan yakni 31 orang responden $(51,7 \%)$ dimana 8 orang responden terdapat pada kelompok kasus dan 23 orang responden terdapat pada kelompok kontrol. Sedangkan kelompok responden terendah terdapat pada kelompok dengan jenis kelamin laki-laki yakni 29 orang responden $(48,3 \%)$ dimana 22 orang responden terdapat pada kelompok kasus dan 7 orang responden terdapat pada kelompok kontrol. Selanjutnya, pada variabel tingkat pendidikan dapat diketahui bahwa responden dengan tingkat pendidikan tertinggi terdapat pada responden dengan tingkat pendidikan terakhir SMA (Sekolah Menengah Atas) yakni sebanyak 27 orang responden $(45,0 \%)$ dimana 12 orang responden terdapat pada kelompok kasus dan 15 orang responden terdapat pada kelompok kontrol. Sedangkan kelompok responden dengan tingkat pendidikan terendah terdapat pada responden yang tidak sekolah yakni sebanyak 2 orang responden $(3,3 \%)$ dimana responden tersebut terdapat pada kelompok kasus.

Untuk mengetahui seberapa besar faktor risiko variabel bebas (tingkat pendidikan, riwayat kontak serumah, kebiasaan merokok keluarga dan kepadatan hunian) terhadap variabel terikat (kejadian Tuberkulosis Paru) dilakukan analisis bivariat yang berupa tabulasi silang antar variabel yang diuraikan pada tabel 2 .

Pada tabel 2, berdasarkan hasil uji statistik yang dilakukan pada variabel tingkat pendidikan responden dengan kejadian Tuberkulosis Paru menunjukkan tidak ada hubungan bermakna secara statistik antara tingkat pendidikan responden dengan kejadian Tuberkulosis Paru di wilayah kerja Puskesmas Bambu Apus dengan nilai $(p=0,19)$. Pada variabel lain, hasil analisis uji statistik yang dilakukan pada variabel riwayat kontak keluarga serumah dengan kejadian Tuberkulosis Paru menunjukkan bahwa ada hubungan bermakna secara statistik antara riwayat kontak keluarga serumah dengan kejadian Tuberkulosis Paru di wilayah kerja Puskesmas Bambu Apus dengan nilai $\mathrm{OR}=$ $3,50$ (95\% CI: 1,112-11,017; $p=0,02)$. Hal ini menujukkan bahwa orang yang memiliki riwayat kontak serumah memiliki risiko 3.5 kali untuk menderita Tuberkulosis Paru. Selanjutnya, hasil analisis uji statistik yang dilakukan pada variabel kebiasaan merokok keluarga dengan kejadian Tuberkulosis Paru menunjukkan adanya hubungan bermakna secara statistik antara kebiasaan merokok keluarga dengan kejadian Tuberkulosis Paru di wilayah kerja Puskesmas Bambu Apus dengan nilai OR= 4,33 (95\% CI:

Tabel 2. Hasil Analisis Bivariat Berdasarkan Variabel Penelitian

\begin{tabular}{|c|c|c|c|c|}
\hline Variabel & Kasus & Kontrol & P Value & Odds Ratio $(95 \% \mathrm{CI})$ \\
\hline \multicolumn{5}{|l|}{ Tingkat Pendidikan } \\
\hline Rendah & 17 & 12 & $0,196^{* *}$ & $1,962(0,702-5,479)$ \\
\hline Tinggi & 13 & 18 & & \\
\hline \multicolumn{5}{|l|}{ Riwayat Kontak serumah } \\
\hline Ada & 14 & 6 & $0,028 *$ & $3,500(1,112-11,017)$ \\
\hline Tidak ada & 16 & 24 & & \\
\hline \multicolumn{5}{|l|}{$\begin{array}{l}\text { Kebiasaan Merokok Kelu- } \\
\text { arga }\end{array}$} \\
\hline Merokok & 26 & 18 & $0,020^{*}$ & $4,333(1,203-15,605)$ \\
\hline Tidak Merokok & 4 & 12 & & \\
\hline \multicolumn{5}{|l|}{ Kepadatan Hunian } \\
\hline Padat & 10 & 11 & $0,787 * *$ & $0,864(0,299-2,498)$ \\
\hline Tidak Padat & 20 & 19 & & \\
\hline $\begin{array}{l}\text { *Variabel yang berhubungan } \\
\text { **Variabel yang tidak berhubungan }\end{array}$ & & & & \\
\hline
\end{tabular}


1,203-15,605; $\mathrm{p}=0,02)$. Hal ini juga menujukkan bahwa orang yang anggota keluarga serumahnya memiliki kebiasaan merokok, memiliki risiko 4 kali untuk menderita Tuberkulosis Paru.

Selain pada ketiga variabel di atas, pada penelitian ini juga dilakukan analisis uji statistik pada variabel kepadatan hunian dengan kejadian Tuberkulosis Paru. Hasil analisis uji statistik yang dilakukan menunjukkan tidak ada hubungan bermakna secara statistik antara kepadatan hunian dengan kejadian Tuberkulosis Paru di wilayah kerja Puskesmas Bambu Apus dengan nilai $(p=0,78)$.

\section{DISKUSI}

Menurut teori Lawrance Green, Tingkat pendidikan merupakan salah satu faktor predisposisi (faktor pemudah) dalam mewujudkan perilaku kesehatan (Notoatmodjo S, 2012). Hasil Penelitian ini sejalan dengan penelitian yang dilakukan oleh (Fitriani E, 2013) di Kabupaten Brebes yang menyatakan bahwa tidak terdapat hubungan antara tingkat pendidikan dengan penderita Tuberkulosis Paru di wilayah kerja Puskesmas Ketanggungan. Tidak ditemukannya hubungan antara tingkat pendidikan dengan kejadian Tuberkulosis Paru diduga karena banyaknya responden dalam penelitian ini baik pada kelompok kasus maupun kelompok kontrol yang tingkat pendidikannya menengah ke atas.

Selanjutnya, pada variabel riwayat kontak serumah, hasil penelitian ini menunjukkan bahwa adanya hubungan yang signifikan dengan kejadian Tubekulosis Paru. Penderita penyakit Tuberkulosis Paru kemungkinan besar akan menularkan kuman Tuberkulosis pada orang yang menghabiskan waktu sepanjang hari dengan mereka, dalam hal ini termasuk anggota keluarga, teman dan rekan kerja atau teman sekolah (Centers for Disease Control and Prevention, 2016). Hasil penelitian ini sejalan dengan penelitian yang dilakukan oleh (Fitriani E, 2013) di Kabupaten Brebes yang menyatakan bahwa terdapat hubungan antara riwayat kontak dengan kejadian Tuberkulosis Paru di wilayah kerja Puskesmas Ketanggungan dengan nilai OR sebesar 5 kali. Penelitian ini juga sejalan dengan penelitian yang dilakukan (Rohayu N, 2016) di Kabupaten Buton Selatan yang menyatakan ada hubungan antara riwayat kontak dengan kejadian
Tuberkulosis Paru di wilayah kerja Puskesmas Kadatua. Pada penelitian yang dilakukan oleh (Rohayu N, 2016) didapatkan bahwa orang yang memiliki riwayat kontak 5 kali berisiko menderita Tuberkulosis Paru.

Terdapatnya hubungan antara riwayat kontak serumah dengan kejadian Tuberkulosis Paru di wilayah kerja Puskesmas Bambu Apus diduga disebabkan oleh sebahagian besar dari responden yang diteliti pada kelompok kasus maupun kontrol memiliki riwayat kontak dengan penderita Tuberkulosis Paru sebelumnya. Hal ini didukung dengan hasil observasi di lapangan yang menunjukkan banyaknya responden yang anggota keluarganya sedang atau pernah menderita Tuberkulosis Paru. Sebagaimana diketahui bahwa Mode of transmission penyakit Tuberkulosis Paru dapat melalui droplet, sehingga keterpaparan dengan droplet penderita Tuberkulosis Paru pada mereka yang tinggal serumah akan lebih tinggi dibandingkan tidak tinggal serumah.

Pada variabel kebiasaan merokok, peneliti melihat sejauh mana kebiasaan merokok anggota keluarga serumah mempengaruhi keterpaparan Tuberkulosis Paru. Hasil uji statistik menunjukkan adanya hubungan yang signifikan antara kebiasaan merokok anggota keluarga dengan kejadian Tuberkulosis Paru di wilayah kerja Puskesmas Bambu Apus. Kebiasaan merokok dan atau menghisap asap rokok (perokok pasif) memperburuk gejala Tuberkulosis Paru pada individu. Dimana perokok pasif akan lebih mudah terinfeksi bakteri Microbacterium tuberculosis. Hal ini disebabkan asap rokok memiliki dampak buruk pada daya tahan paru terhadap bakteri. Hasil penelitian ini sejalan dengan penelitian yang dilakukan oleh (Lalombo dkk., 2015) di Kabupaten Kepulauan Sangihe yang menyatakan bahwa terdapat hubungan antara kebiasaan merokok dengan kejadian Tuberkulosis Paru di wilayah kerja Puskesmas Ketanggungan dengan nilai OR sebesar 5,4 kali. Tingginya persentase kebiasaan merokok anggota keluarga yang mencapai $71,7 \%$ diduga menjadi faktor penyebab adanya hubungan antara kebiasaan merokok anggota keluarga serumah dengan kejadian Tuberkulosis Paru.

Kepadatan hunian juga merupakan variabel yang diteliti dalam penelitian ini. Hasil 
uji statistik pada variabel kepadatan hunian menunjukkan tidak adanya hubungan yang signifikan secara statistik antara kepadatan hunian dengan kejadian Tuberkulosis Paru di wilayah kerja Puskesmas Bambu Apus. Hasil Penelitian ini tidak sejalan dengan penelitian yang dilakukan oleh (Rohayu N, 2016) di Kabupaten Buton Selatan yang menyatakan bahwa terdapat hubungan antara kepadatan hunian dengan kejadian Tuberkulosis Paru di wilayah kerja Puskesmas Kadatua Kabupaten Buton Selatan. Pada penelitian tersebut diketahui bahwa orang yang tinggal di hunian padat berisiko 8 kali untuk menderita Tuberkulosis Paru.

Walaupun hasil penelitian ini tidak menunjukkan adanya hubungan antara variabel kepadatan hunian dengan kejadian Tuberkulosis Paru di wilayah kerja Puskesmas Bambu Apus namun variabel ini berpotensi memiliki dampak di masa yang akan datang mengingat banyaknya responden yang berdomisili dengan status hunian padat. Hal ini didukung hasil observasi yang menunjukkan banyaknya responden yang tinggal di kost - kostan di wilayah Kecamatan Pamulang Kota Tangerang selatan. Selain itu tidak terdapatnya hubungan antara kepadatan hunian dengan kejadian Tuberkulosis Paru diduga dipengaruhi oleh proporsi kepadatan hunian pada kelompok kasus dan kontrol yang hampir sama.

\section{KESIMPULAN}

Berdasarkan hasil penelitian yang telah dilakukan dapat disimpulkan bahwa riwayat kontak serumah dengan penderita Tuberkulosis Paru dan kebiasaan merokok keluarga memiliki hubungan secara statistik dan merupakan faktor risiko kejadian Tuberkulosis Paru sedangkan tingkat pendidikan responden dan kepadatan hunian tidak memiliki hubungan secara statistik dan bukan merupakan faktor risiko kejadian Tuberkulosis Paru di wilayah kerja Puskesmas bambu Apus, Kota Tangerang Selatan. Sehingga, berdasarkan hasil penelitian ini, peneliti merekomendasikan untuk terus meningkatkan upaya kegiatan preventif dan promotion khususnya pada faktor risiko Tuberkulosis Paru yang dipengaruhi oleh faktor perilaku anggota keluarga.

\section{DAFTAR PUSTAKA}

Centers for Disease Control and Prevention. (2016). How TB Spreads.

Retrieved from

https://www.cdc.gov/tb/topic/basics/h owtbspreads.htm

Fitriani, Eka. (2013). Faktor Risiko Yang Berhubungan Dengan Kejadian Tuberkulosis Paru (Studi Kasus di Puskesmas Ketanggungan Kabupaten Brebes Tahun 2012). Unnes Journal of Public Health, 2(1), 2-5.

Retrieved from https://doi.org/https://doi.org/10.1529 4/ujph.v2i1.3034

Kementerian Kesehatan RI. (2016). Profil Data Kesehatan Indonesia. Jakarta

Kementerian Kesehatan RI. (2018). Pusat Data dan Informasi Kementerian Kesehatan RI; Tuberkulosis. Jakarta.

Retrieved from

http://www.depkes.go.id/download. php?file=download/pusdatin/infodatin/ infodatin\%20tuberkulosis\%202018.pdf

Lalombo, A. Yulied., Palandeng, Henry., Kallo, D. Vanri., (2015). Hubungan Kebiasaan Merokok dengan Kejadian Tuberkulosis Paru di Puskesmas Siloam Kecamatan Tamako Kabupaten Kepulauan sangihe.

Retrieved from https://ejournal.unsrat.ac.id/index.php/jkp/ article/view/7529/7081

Lameshow, S., Hosmer, D. W., Klar, J. Lwanga, S.(1997). Besar Sampel Dalam Penelitian Kesehatan. Yogyakarta: Gadjah Mada University Press.

Notoatmodjo, S. 2012. Promosi Kesehatan dan Perilaku Kesehatan. Cetakan Ke-1 Jakarta: PT. Rineka Cipta

Rohayu, Nurliza. (2016). Analisis Faktor Risiko Kejadian TB Paru BTA Positif Pada Masyarakat Pesisir Di Wilayah Kerja Puskesmas Kadatua Kabupaten Buton Selatan Tahun 2016, 58, 1-15. Retrieved from http://ojs.uho.ac.id/index.php/JIMKE\%20 SMAS/article/view/1257/903

UMK Provinsi Banten. (2018). Keputusan Gubernur Banten Nomor 561/Kep. 442-Huk/2017. Banten Retrieved from https://spn.or.id/dppspn/UMK-TAHUN-2018BANTEN.pdf

WHO 2017. Global Tuberculosis Report 2017. Jenewa 